\title{
Variability of summer humidity during the past 800 years on the eastern Tibetan Plateau inferred from $\delta^{18} \mathrm{O}$ of tree-ring cellulose
}

\author{
J. Wernicke, J. Grießinger, P. Hochreuther, and A. Bräuning \\ Institute of Geography, Friedrich-Alexander-University Erlangen-Nuremberg, Erlangen, Germany \\ Correspondence to: J. Wernicke (jakob.wernicke@ fau.de)
}

Received: 2 July 2014 - Published in Clim. Past Discuss.: 15 August 2014

Revised: 8 January 2015 - Accepted: 16 January 2015 - Published: 24 February 2015

\begin{abstract}
We present an 800-year $\delta^{18} \mathrm{O}$ chronology from the eastern part of the Tibetan Plateau (TP). The chronology dates back to AD 1193 and was sampled in AD 1996 from living Juniperus tibetica trees. This first long-term tree-ringbased $\delta^{18} \mathrm{O}$ chronology for eastern Tibet provides a reliable archive for hydroclimatic reconstructions. Highly significant correlations were obtained with hydroclimatic variables (relative humidity, vapour pressure, and precipitation) during the summer season. We applied a linear transfer model to reconstruct summer season relative humidity variations over the past 800 years. More moist conditions prevailed during the termination of the Medieval Warm Period while a systematic shift during the Little Ice Age is not detectable. A distinct trend towards more dry conditions since the 1870s is apparent. The moisture decline weakened around the 1950s but still shows a negative trend. The mid-19th century humidity decrease is in good accordance with several multiproxy hydroclimate reconstructions for south Tibet. However, the pronounced summer relative humidity decline is stronger on the central and eastern TP. Furthermore, the relative humidity at our study site is significantly linked to the relative humidity at large parts of the TP. Therefore, we deduce that the reconstructed relative humidity is mostly controlled by local and mesoscale climatic drivers, although significant connections to the higher troposphere of west-central Asia were observed.
\end{abstract}

\section{Introduction}

The variation in strength, timing, and duration of the Asian summer monsoon (ASM) system affects the life and econ- omy of many millions of people living in south and east Asia (Immerzeel et al., 2010; Zhang et al., 2008). In remote areas, such as the Tibetan Plateau (TP), reliable climate records are short and scattered. Nevertheless, a recent weakening trend of the ASM precipitation amount was reported in several studies (Bollasina et al., 2011; Sano et al., 2011; Zhou et al., 2008b). The decline in air humidity was explained by a reduction in the thermal gradient between the surface temperatures of the Indian Ocean and the TP due to global warming (Sun et al., 2010). Different locations and climate archives reveal contemporaneous strengthened monsoonal precipitation (Anderson et al., 2002; Kumar et al., 1999; Zhang et al., 2008). This discrepancy may be explained by the high variability of the monsoon circulation itself and also by the limited number of available palaeoclimate studies and resulting climate modelling uncertainties. Thus, for a better understanding of the circulation system as a whole, but also for the verification of climate change scenarios, a keen demand for reliable climate reconstructions exists for the TP. With increasing numbers of palaeoclimatic records, forecast and climate projection precision increases and can be helpful for facilitating targeted decision-making regarding water and resource management.

The northward movement of the Intertropical Convergence Zone (ITCZ) in the Northern Hemisphere in boreal summer is amplified over the Asian continent by the thermal contrast between the Indian Ocean and the TP (Webster et al., 1998). Convective rainfalls during the summer monsoon season between June and September are strongly altered by the complex topography of the Himalayas and western Chinese mountain systems (e.g. Böhner, 2006; Maussion et al., 2014; Thomas and Herzfeld, 2004). Extreme climatic 


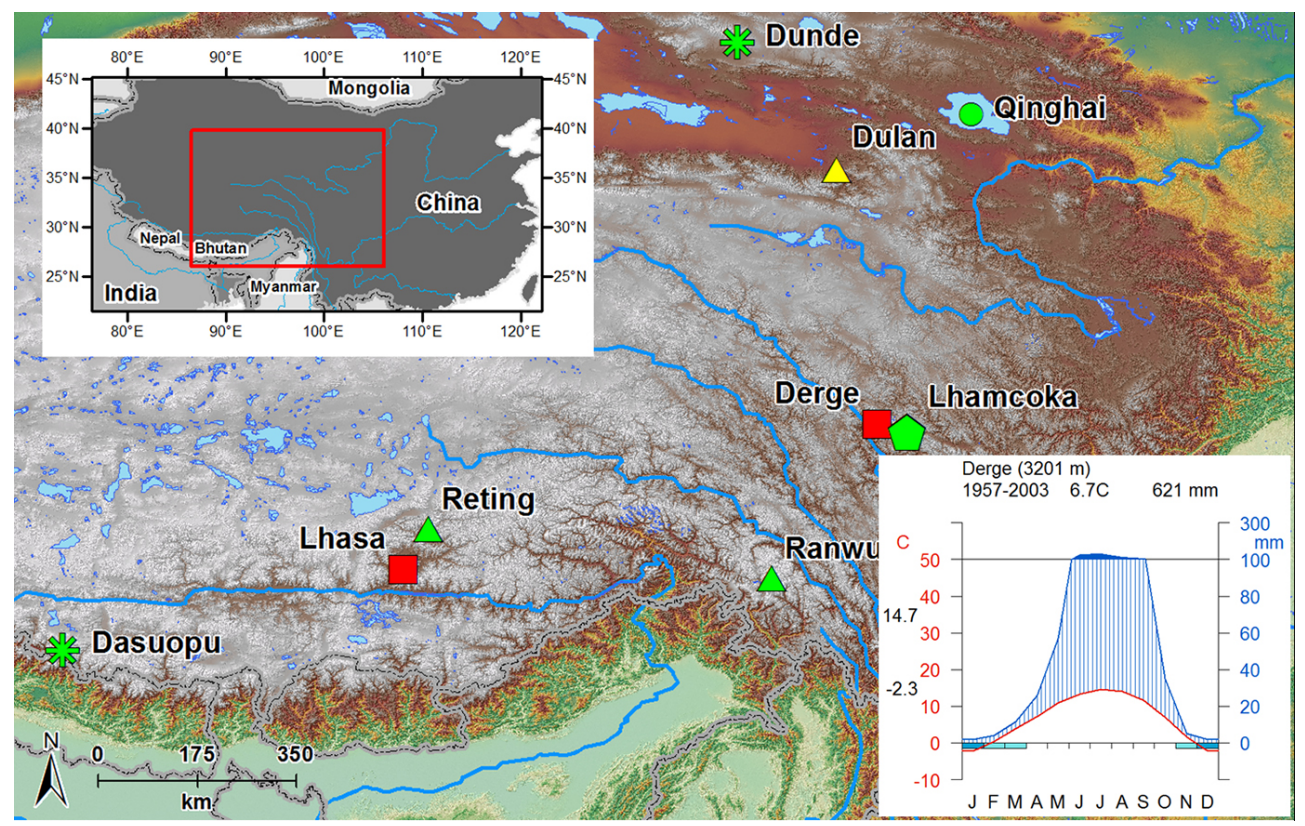

Figure 1. Location of the study site Lhamcoka (green pentagon) and other proxy archives mentioned in the text. Green triangles: treering $\delta^{18} \mathrm{O}$ chronologies; yellow triangle: tree-ring width chronology; green asterisk: ice cores; green circle: lake sediments. Red rectangles indicate climate stations.

events that may have devastating effects and the long-term trends of ASM intensity are therefore in the focus of numerous climate reconstruction efforts (e.g. Cook et al., 2010; $\mathrm{Xu}$ et al., 2006b; Yang et al., 2003). Most of these studies use tree-ring width as a proxy for palaeoclimate reconstructions. Nonetheless, several studies demonstrated that $\delta^{18} \mathrm{O}$ of wood cellulose is a strong indicator of hydroclimatic conditions (McCarroll and Loader, 2004; Roden et al., 2000; Saurer et al., 1997; Sternberg, 2009). Even if tree stands might have been influenced by external disturbances (e.g. competition, insect attacks, or geomorphological processes) they still reflect variations of the local hydroclimate accurately (Sano et al., 2013). Recently published tree-ring $\delta^{18} \mathrm{O}$ chronologies from the TP show a common strong response to regional moisture changes. Grießinger et al., 2011 successfully reconstructed August precipitation over the past 800 years. They demonstrated reduced precipitation during the Medieval Warm Period (MWP), stronger rainfalls during the Little Ice Age (LIA), decreasing precipitation rates since the 1810s, and slightly wetter conditions since the 1990s. In addition, shorter $\delta^{18} \mathrm{O}$ chronologies from the central Himalayas showed consistent negative correlations to summer precipitation (Sano et al., 2010, 2011, 2013). The detected recent reduction of monsoonal precipitation has been interpreted as a reaction to increased sea surface temperatures (SSTs) over the tropical Pacific and Indian Ocean (Zhou et al., 2008a). Strong responses to regional cloud cover changes were found for tree-ring $\delta^{18} \mathrm{O}$ chronologies from the south-eastern TP (Liu et al., 2013; Liu et al., 2014; Shi et al., 2012). The local moisture reduction starting in the middle of the 19th century is less pronounced than for south-west Tibet, and is associated with complex El Niño-Southern Oscillation (ENSO) teleconnections (Liu et al., 2012). Existing tree-ring $\delta^{18} \mathrm{O}$ chronologies on the north-eastern part of the TP respond to local precipitation and relative humidity (Wang et al., 2013; Liu et al., 2008). Except for a relatively short summer moisture-sensitive time series (An et al., 2014), no longterm $\delta^{18} \mathrm{O}$ chronologies or reliable reconstructions have been conducted for the eastern TP so far. It still remains unclear to what extent the MWP, LIA, and the modern humidity decrease are reflected in tree-ring $\delta^{18} \mathrm{O}$ on the eastern TP, where the influence of the ASM, the Indian Summer monsoon and the westerlies overlap.

We present a new, well-replicated 800 -year $\delta^{18} \mathrm{O}$ chronology, representing a unique archive for studying the past hydroclimate in eastern Tibet. We applied response and transfer functions and obtained a reliable reconstruction of summer relative humidity (July + August). We compared the long-term trend of our chronology to other moisture-sensitive proxy archives from several sites over the TP and discuss climatic control mechanisms on the relative humidity.

\section{Material and methods}

\subsection{Study site - Lhamcoka}

Lhamcoka is located on the eastern TP (see Fig. 1 green pentagon). During a field campaign in 1996, 16 living Juniperus tibetica trees were cored twice in order to enhance the 


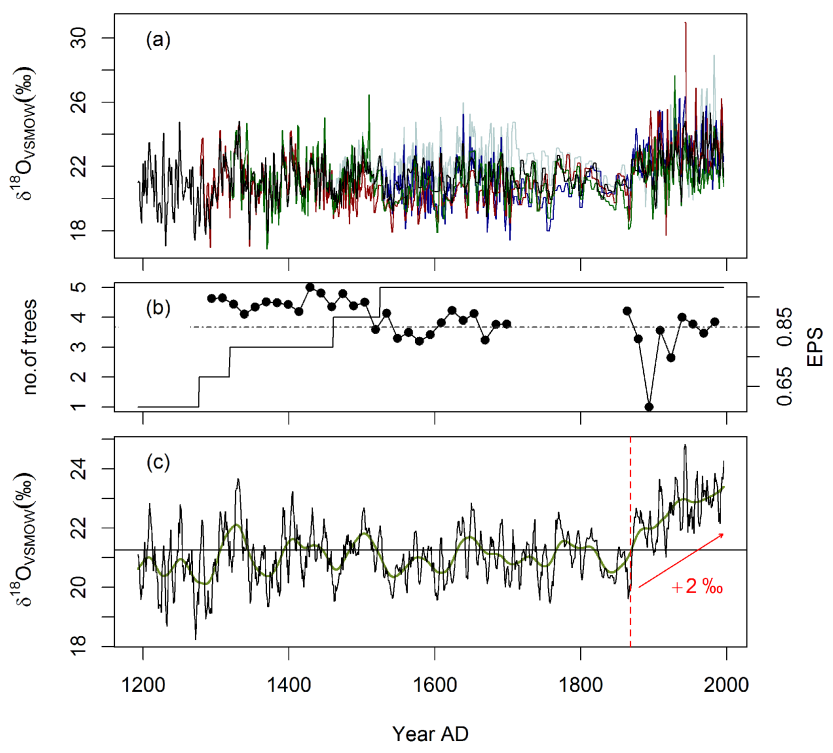

Figure 2. Lhamcoka tree-ring $\delta^{18} \mathrm{O}$ isotope chronology. (a) Individual $\delta^{18} \mathrm{O}$ time series of five individuals. The coarse resolution between 1707 and 1864 results from shifted block pooling. (b) Running EPS (calculated for 25-year intervals, lagged by 10 years) and number of trees used for the reconstruction (solid line). Dashed line represents the theoretical EPS threshold of 0.85 . (c) Tree-ring $\delta^{18} \mathrm{O}$ chronology spanning the period AD 1193-1996. Green solid line represents a 50-year smoothing spline. The red dashed line marks the turning point towards heavier isotope ratios after $\sim 1870$.

chance of detecting missing rings. The samples were collected from a steep, south-east exposed slope at an elevation of $4350 \mathrm{~m}$ a.s.1. $\left(31^{\circ} 49^{\prime} \mathrm{N}, 9^{\circ} 06^{\prime} \mathrm{E}\right)$. The oldest tree is 801 years old, resulting in an overall chronology time span of AD 1193-1996. The average single core length is 633 years, with single segment lengths of $801 \mathrm{yr}, 697 \mathrm{yr}, 668 \mathrm{yr}, 528 \mathrm{yr}$, and $469 \mathrm{yr}$. The chronology is not biased by an age trend as it was supposed for different high-altitude mountain ecosystems (Esper et al., 2010; Treydte et al., 2006). We applied a spline-based trend analysis and revealed non-systematic trends during the first 100 years after germination (graph not shown here). Therefore, a "juvenile" effect is not likely to affect our chronology, justifying the retention of the oldest parts of each single core. Juniper forms the upper timberline in the region due to its cold temperature tolerance (Bräuning, 2001). The species' annual tree-ring growth is limited by temperature and spring precipitation (FebruaryApril) (see Lhamcoka E site description in Bräuning, 2006). Therefore, the early wood formation is negatively affected by spring conditions, leading to growth reduction of the annual growth rings. Due to the steep slope angle of more than $30^{\circ}$ and well-drained substrate properties at the study site, ground water influence can be excluded. Therefore, we assume the trees $\delta^{18} \mathrm{O}$ source water properties are mainly controlled by the oxygen isotope configuration of summer precipitation, although it is known that snow-derived meltwater input affects the source water properties of trees (Treydte et al., 2006). According to dry and cold winter monsoon conditions (see climate diagram in Fig. 1), a high and persistent snow cover at our study site is not likely. Hence, $13 \%$ of potential solid precipitation falling between October and April will probably not strongly influence the source water properties at our study site.

Lhamcoka is influenced by the Indian summer monsoon system with typical maxima of temperature and precipitation during the summer months (see climate diagram in Fig. 1). The nearby climate station Derge (3201 m a.s.1., $50 \mathrm{~km}$ from the sampling site) records $78 \%(541 \mathrm{~mm})$ of annual precipitation between June and September, which is in accordance with common monsoonal climate properties (Böhner, 2006). The Derge climate record (data provided by the China Meteorological Administration) revealed increasing temperatures of about $0.6^{\circ} \mathrm{C}$ during the period $1956-1996$, whereas the amount and interannual variability of precipitation remained constant within these 41 years.

Five trees were chosen for isotope analysis to adequately capture inter-tree variability of $\delta^{18} \mathrm{O}$ (Leavitt, 2010). The trees were selected for the (i) old age of the cores, to maximize the length of the derived reconstruction, (ii) avoidance of growth asymmetries due to slope processes, (iii) sufficient amounts of material (samples with wider rings were favoured), and (iv) high inter-correlation among the tree-ring width series of the respective cores.

\subsection{Sample preparation}

We used the tree-ring width master chronology of Bräuning, 2006 in order to date each annual ring precisely. The dated tree-rings were cut with a razor blade under a microscope. $\delta^{18} \mathrm{O}$ values were measured from each tree individually in annual resolution. During periods of the chronology with extremely narrow rings, we used shifted block pooling to obtain sufficient material (Böttger and Friedrich, 2009). Pooling was applied between the years 1707 and 1864 (see chronology parts with missing expressed population signal (EPS) in Fig. 2). To obtain pure $\alpha$-cellulose, we followed the chemical treatment presented in Wieloch et al., 2011. The $\alpha$-cellulose was homogenized with an ultrasonic unit and the freeze-dried material was loaded into silver capsules (Laumer et al., 2009). The ratio of ${ }^{18} \mathrm{O} /{ }^{16} \mathrm{O}$ was determined in a continuous flow mass spectrometer (Delta V Advantage; Thermo Fisher Scientific Inc.). The standard deviation for the repeated measurement of an internal standard was better than $0.25 \%$.

\subsection{Statistical analyses}

We used standard dendrochronology techniques of chronology building, model building, and verification for reliable climate reconstruction (Cook and Kairiukstis, 1990). All analysis were conducted with the open source statistical software 
$\mathrm{R}$ (http://cran.r-project.org/). The stable isotope chronology was calculated within the "dplR" package developed by Bunn, 2008 and the dendroclimatological correlation and response analyses were conducted by the "bootRes" package (Zang and Biondi, 2012). The pooling method we executed required a running mean calculation. Thus, the presented chronology has a quasi-annual resolution, smoothed with a 5 -year running mean filter. To evaluate the isotope chronology reliability, the EPS (introduced by Wigley et al., 1984) and the Gleichläufigkeit (GLK) were computed. The EPS expresses the variance fraction of a chronology in comparison with a theoretically infinite tree population, whereas the GLK specifies the proportion of agreements/disagreements of interannual growth tendencies among the trees of the study site. The EPS is interrupted within our $\delta^{18} \mathrm{O}$ chronology at parts where we applied shifted block pooling.

\section{Results}

\subsection{Chronology characteristics}

The Lhamcoka $\delta^{18} \mathrm{O}$ chronology is defined by a mean of $21.27 \%$ and global minima/maxima of $18.24 \%$ o $24.83 \%$. The values are similar to results from nearby studies (An et al., 2014; Liu et al., 2012; Liu et al., 2013). Moreover, the trees within the chronology are characterized by a common signal that is expressed by an EPS of 0.88 and a highly significant GLK of $0.57(p<0.01)$. Thus, our selected trees are likely to be affected by a common force, a prerequisite for compiling a reliable mean $\delta^{18} \mathrm{O}$ chronology. The chronology can be sub-divided into two parts (see Fig. 2). The younger section (AD 1868-1996) shows a pronounced trend of about $2 \%$ o towards heavy isotope ratios. Within this segment, the year with the heaviest ratio was detected in $\mathrm{AD}$ $1943\left(24.8 \%\right.$ o). Before the late 1870 s, the isotope $\delta^{18} \mathrm{O}$ values oscillate around the chronology mean. A phase of considerable low $\delta^{18} \mathrm{O}$ values is obvious from AD 1200 to 1300 . Within this section, the lightest isotope ratio was detected in AD $1272(18.2 \%$ o). The signal strength (EPS) occasionally drops below the commonly accepted threshold of 0.85 during several periods. One reason might be the imprecise cutting of very narrow rings (ring width $<0.2 \mathrm{~mm}$ ). A mix of several rings produces a signal that cannot be related with certainty to a specific year, a well-known problem when using very old trees (Berkelhammer and Stott, 2012; Xu et al., 2013). Nevertheless, we have confidence in the Lhamcoka chronology due to an EPS above the threshold during the period $\mathrm{AD} 1300-1700$.

\subsection{Climatic response of tree-ring stable oxygen isotopes}

We conducted linear correlation analyses between the $\delta^{18} \mathrm{O}$ values and monthly climate data as well as calculated seasonal means of climate elements. The available climate

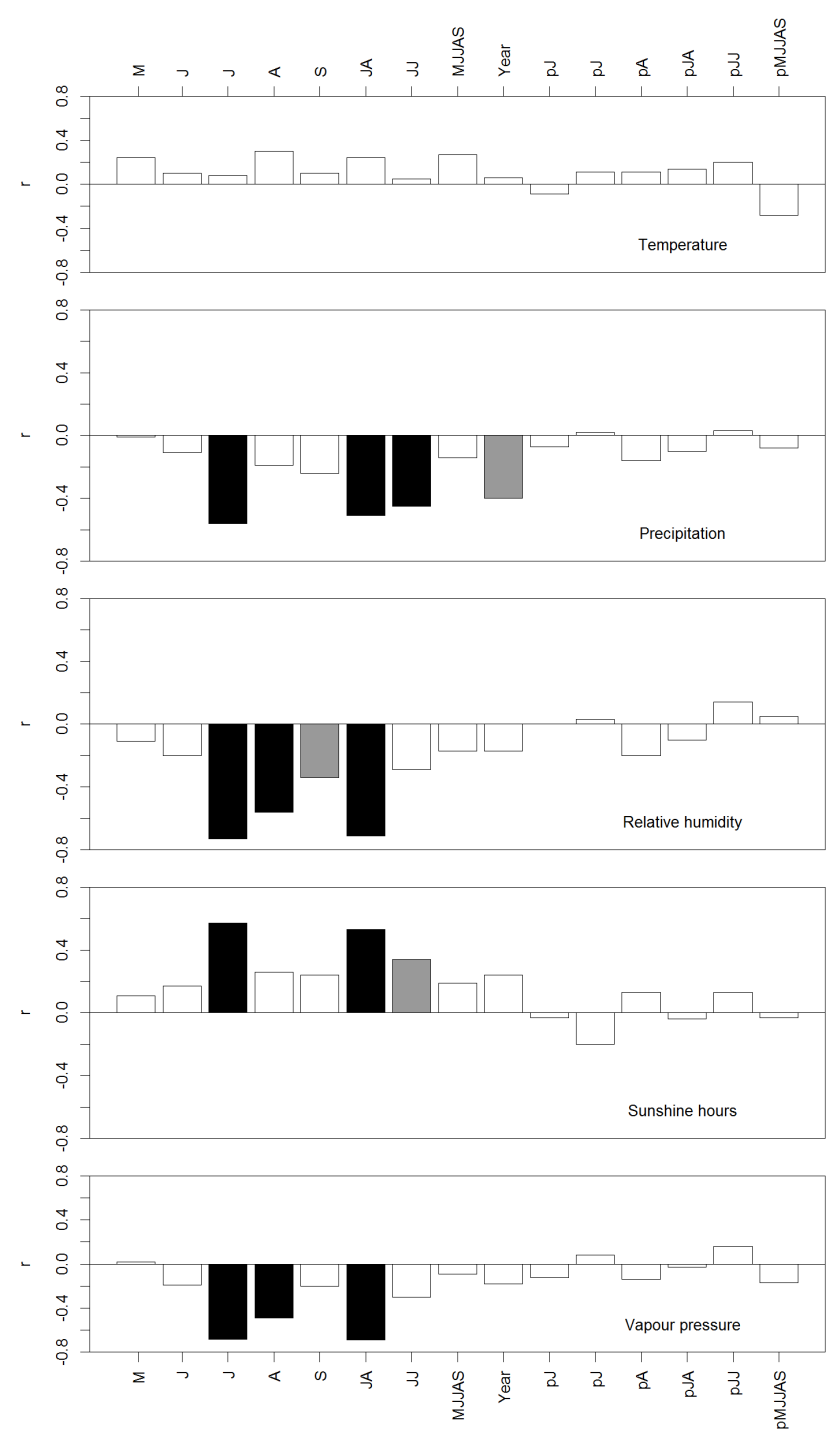

Figure 3. Response of tree-ring $\delta^{18} \mathrm{O}$ to monthly/seasonal temperature, precipitation, relative humidity, sunshine hours, and vapour pressure over the period AD 1956-1996. Gray and black bars indicate correlations significant at $p<0.05$ and $p<0.01$, respectively; $p$ indicates months/seasons of the previous year.

record of station Derge covers 41 years (AD 1956-1996) and correlations were calculated for temperature (mean), precipitation, relative humidity, sunshine hours (duration of global radiation $>120 \mathrm{~W} \mathrm{~m}^{-2}$ ), and vapour pressure (see Fig. 3).

Summer moisture conditions explain most of the variance of the $\delta^{18} \mathrm{O}$ chronology during the calibration period (AD 1956-1996). The stable oxygen isotopes are highly significantly $(p<0.01)$ correlated with precipitation, relative humidity, sunshine hours, and vapour pressure during July and August. Highest (negative) correlations were obtained with relative humidity during July $(r=-0.73)$ and July/August $(r=-0.71)$. Thus, if relative humidity is high, transpiration is lowered and the depletion of light $16 \mathrm{O}$ due to leaf 
Table 1. Verification statistics according to the linear transfer model of $\delta^{18} \mathrm{O}$ and relative humidity within the calibration period AD 1956-1996.

\begin{tabular}{ll} 
Sign test (ST) & $0.73(p<0.1)$ \\
Product-moment correlation (PMC) & $0.67(p<0.01)$ \\
Product means test (PMT) & $3.3(p<0.01)$ \\
Reduction of error (RE) & 0.45 \\
Coefficient of efficiency (CE) & 0.45 \\
\hline
\end{tabular}

water fractionation is reduced. Additionally, weak and nonsignificant relationships were found with the mean temperature in all months/seasons. Thus, concepts of integrated temperature-moisture indexes, e.g. the vapour pressure difference (VPD: Kahmen et al., 2011), are unlikely to explain more of the variance in our data. However, we calculated the VPD as the difference between water vapour saturation pressure $(E)$ and vapour pressure $(e)$ and correlated the VPD time series against the $\delta^{18} \mathrm{O}$ during the calibration period. From this we obtained significant but slightly weaker relationships with VPD $(r=0.68, p<0.01)$ since relative humidity and VPD are both influenced by temperature. Moreover, sunshine hours are positively related to the $\delta^{18} \mathrm{O}$ variation. This association of high sunshine hours, less cloudiness, decreased relative humidity, and thus increased $\delta^{18} \mathrm{O}$ values was corroborated by findings for south-east Tibet (Shi et al., 2012). Very weak correlations were found with climate conditions during the previous year. Therefore, plant physiological carryover effects as well as stagnating soil water can be regarded as insignificant factors for tree-ring $\delta^{18} \mathrm{O}$ variations. The explained variance of the linear regression model between annual stable oxygen isotope values and relative humidity is $53 \%$. Hence, the $\delta^{18} \mathrm{O}$ value mainly depends on relative humidity, which is in accordance with the findings of Roden and Ehleringer, 2000. Although highest correlations were obtained with single months (July: $r=-0.73(p<0.01)$ ), the reconstruction was established for the summer season (mean relative humidity of July and August). In terms of using the wood cellulose of a single year, the humidity reconstruction of the major growing season is more robust than for single months.

\subsection{Reconstruction of relative humidity}

We employed a linear model for the reconstruction of relative humidity over the past 800 years. The linear relationship was achieved for the $\delta^{18} \mathrm{O}$ values and instrumental records of relative humidity at climate station Derge between AD 1956 and 1996. The model was validated according to the standard methods presented in Cook and Kairiukstis, 1990, and Cook et al., 1994. We applied the leave-one-out validation procedure due to the short time period of available climate data. The model statistics are summarized in Table 1.

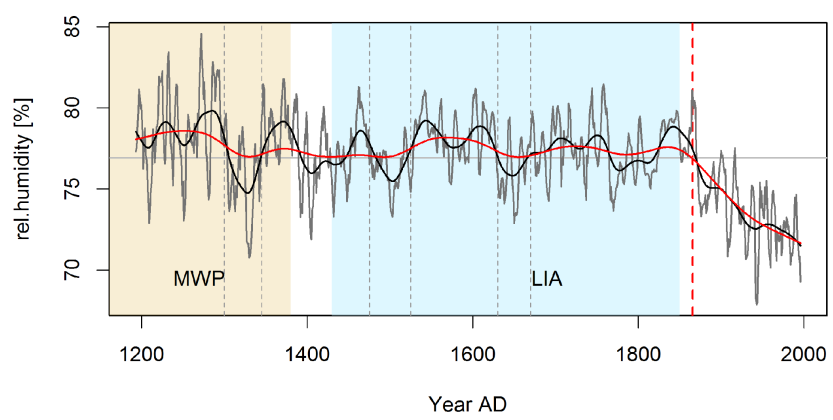

Figure 4. Summer (July + August) relative humidity reconstruction AD 1193-1996 for the eastern TP. Solid black and red lines represent 50-year and 150-year smoothing splines, respectively. Red dashed line emphasizes the turning point towards drier conditions $(\sim 1870 s)$. The horizontal gray line illustrates mean relative summer humidity $(\mathrm{RH}=72.4 \%)$. Vertical dashed lines mark relatively dry periods. The Medieval Warm Period (MWP) and Little Ice Age (LIA) are emphasized in yellow and blue.

The validation tests indicated that (1) the number of agreements between the reconstructed climate series and the meteorological record is determined according to the sign orientation significantly different from a pure chance driven binomial test (ST); (2) the cross-correlation between the reconstruction and the measurement is highly significant (PMC, PMT), and (3) the reconstruction is reliable due to a positive RE and CE, indicating the reconstruction is better than the calibration period mean (Cook et al., 1994). Thus, our linear model is suitable for climate reconstruction purposes. The model related to the reconstruction of summer relative humidity is described as $\mathrm{RH}_{\mathrm{JA}}=-2.3 \cdot \delta^{18} \mathrm{O}+125.3\left(\mathrm{RH}_{\mathrm{JA}}\right.$ expressed in percentage). A negative relationship between tree-ring stable oxygen isotopes and relative humidity was documented properly in several studies around the globe and among different species (Anderson et al., 1998; Burk and Stuiver, 1981; Ramesh et al., 1986; Tsuji et al., 2006). However, due to varying environmental settings (e.g. climate, soil) and different biological leaf properties (Kahmen et al., 2009), the slopes of the regression function differ significantly among study sites and species. Hence, $\delta^{18} \mathrm{O}$ inferred model parameters from a neighbouring summer relative humidity reconstruction (June-August) using Abies trees differ from our regression model (An et al., 2014).

Our reconstruction reveals several phases of high and low summer humidity (see Fig. 4). Negative deviations from the mean value $(72.4 \%$; $\mathrm{sd}=4.9 \%)$ occurred during $\mathrm{AD} 1300$ 1345, AD 1475-1525, AD 1630-1670, and AD 1866-1996 (periods are emphasized with dashed vertical lines in Fig. 4). The most pronounced relative humidity depression started in the late 1870s (dashed red line in Figure 4) and lasts until approximately the 1950s. The period is characterized by the driest summer in AD $1943(\mathrm{RH}=68.4 \%)$. The remarkable moisture reduction since the end of the LIA has been validated for the southern and south-eastern part of the TP (Liu 

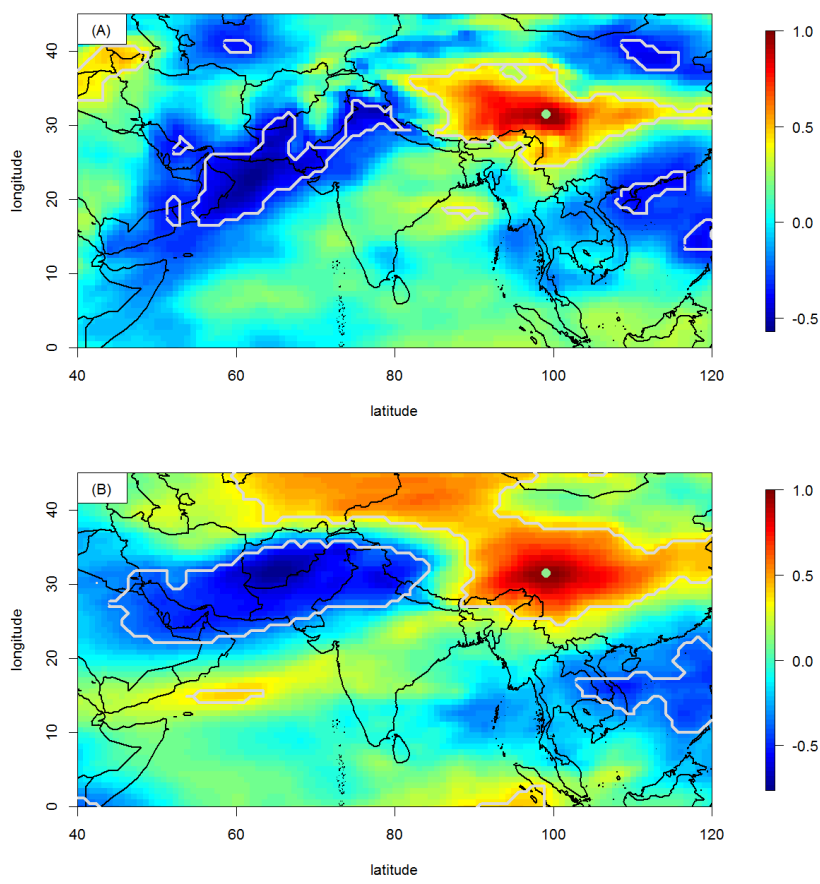

Figure 5. Spatial correlation of July-August relative humidity (ERA interim data, AD 1979-2013) at the (a) $500 \mathrm{hPa}$ and (b) $300 \mathrm{hPa}$ pressure level. Colour code represents the Pearson correlation coefficient. White lines delineate the $95 \%$ significance level. Proxy location is shown by the light green dot.

et al., 2014; Xu et al., 2012; Zhao and Moore, 2006). After approximately the 1950 s, a clear trend towards even drier conditions is attenuated (trend slope $=0.01, p=0.63$ ). This finding is in accordance with results from the central and south-eastern TP (Grießinger et al., 2011; Liu et al., 2013; Shi et al., 2012) and might be caused by uneven warming trends of the northern and equatorial Indian Ocean sea surface temperatures (Chung and Ramanathan, 2006). More humid periods were detected during AD 1193-1300, AD 13451390, AD 1455-1475, and AD 1740-1750, with the highest relative humidity in AD $1272(\mathrm{RH}=83.5 \%)$. Thus, the MWP is characterized by the highest humidity values within the past 800 years. Similar conditions were observed for inner Asia and the northern TP (Pederson et al., 2014; Yang et al., 2013) but were not corroborated for the central TP (Grießinger et al., 2011). The moderate oscillation of our humidity reconstruction during the LIA contrasts results of increasing and decreasing moisture trends at different parts of the TP (Grießinger et al., 2011; Shao et al., 2005; Yao et al., 2008). We identified extreme interannual humidity variations by calculating the third standard deviation of the first differences. Years with humidity variations above $10 \%$ were detected in AD 1960/1961, AD 1946/1947, AD 1941/1942, AD 1706/1707, AD 1253/1254, AD 1238/1239, AD 1233/1234, AD 1230/1231, and AD 1225/1226.

\section{Discussion}

Lhamcoka is located at the assumed boundary zone of air masses from the Indian Ocean, the South and North Pacific, and Central Asia (Araguás-Araguás et al., 1998). Thus, our study site is likely influenced by the monsoon circulation (Indian and Southeast Asian monsoon) as well as by the westerlies (Morrill et al., 2003). In particular, the long-term spatiotemporal modulation of the monsoon circulation systems has been intensively studied (e.g. Kumar et al., 1999; Wang et al., 2012; Webster et al., 1998) and may significantly control the moisture availability at our study site. The precondition for the formation of the monsoon is the land-sea surface temperature gradient between the Asian land mass and the surrounding oceans (Kumar et al., 1999). However, the monsoon circulation system shows variations at interannual and intraseasonal timescales (Webster et al., 1998). In particular, the ENSO impact on the monsoon circulation has been studied extensively (e.g. Cherchi and Navarra, 2013; Kumar et al., 2006; Park and Chiang, 2010). We tested the influence of ENSO on our humidity reconstruction and achieved no significant relationships, implying an ENSO decoupled climate variability at our proxy site (see interactive discussion of this paper Wernicke et al., 2014). On an intraseasonal timescale, the Madden-Julian Oscillation (MJO) modulates the monsoonal precipitation (Madden and Julian, 1994), where the 30- to 90-day zonal propagation of cloud clusters causes breaks in and strengthening of the monsoonal precipitation (Zhang, 2005). More recently, the monsoon circulation system has been affected by greenhouse gas and aerosol emissions (Hu et al., 2000; Lau et al., 2006). Both induce a positive anomaly of monsoonal precipitation due to the strengthening of the thermal gradient in the upper troposphere.

However, in this study, we primarily focus on the controls of relative humidity at our study site, rather than targeting large-scale atmospheric circulation influences immediately. Therefore, we conducted correlation analysis of the July-August relative humidity at the grid cell of our study site with the July-August relative humidity in the area of 0-45 ${ }^{\circ} \mathrm{N}, 40-120^{\circ} \mathrm{E}$ (ERA Interim data: http://apps.ecmwf. int/datasets/data). Beforehand, we examined the accordance of our summer relative reconstruction and the ERA interim data (mean relative humidity July-August). The significant relationship $(r=0.77, p<0.01)$ suggests that the ERA interim data are likely to represent our relative humidity reconstruction. As shown in Fig. 5a, significant correlations at the $500 \mathrm{hPa}$ pressure level are found with almost the entire TP. This suggests a regional signal, reflecting the strong connection of moisture variability at our study site with moisture variability over the whole TP. However, significant negative relationships were found with the south-west and south-east Asian regions. These correlations are even more evident on the $300 \mathrm{hPa}$ level (Fig. 5b) and show a remarkable spatial pattern. Interestingly, the negative correlation in south-west 
Asia contains the region where Ding and Wang, 2005 defined an index for the westerly wave activity (west central Asia: $35-40^{\circ} \mathrm{N}, 60-70^{\circ} \mathrm{E}$ ). The significance of this finding is corroborated by strong correlations of the mean summer relative humidity in $200 \mathrm{hPa}$ of the west central Asian region and our proxy record $(r=-0.58, p<0.05)$. Several studies highlight the general influence of the ASM as the major driver for Tibetan moisture variability (Araguás-Araguás et al., 1998; Hren et al., 2009; Tian et al., 2007). However, the results of Ding and Wang, 2005, Saeed et al., 2011, Mölg et al., 2014, and our findings indicate that the mid-latitude westerlies influence should be taken into consideration in future studies.

For an analysis of the regional representativeness of our data set, we compared the Lhamcoka $\delta^{18} \mathrm{O}$ chronology with six moisture-sensitive proxies from the TP (see Fig. 6 and locations in Fig. 1), including normalized tree-ring (TR) $\delta^{18} \mathrm{O}$ records (Ranwu TR: Liu et al., 2013; Reting TR: Grießinger et al., 2011), tree-ring width data (Dulan TR: Sheppard et al., 2004), accumulation records (Dasuopu and Dunde ice cores: Thompson et al., 2000) and lake sediments (Qinghai sediment: Xu et al., 2006a). We found significant positive correlations between our time series and the Ranwu $(r=$ $0.55, p<0.01)$, Reting $(r=0.23, p<0.01)$, Dunde $(r=0.16$, $p<0.01)$ and Qinghai $(r=0.22, p<0.1)$ data sets. Only the tree-ring width series of Dulan is negatively correlated with the $\delta^{18} \mathrm{O}$ values of Lhamcoka $(r=-0.16, p<0.01)$. The snow accumulation rate of Dasuopu ice core has no relationship with our $\delta^{18} \mathrm{O}$ chronology $(r=-0.04, p=0.3)$. In the case of weak correlations $(|r|<0.2)$ and due to the degrees of freedom ( $\mathrm{DF}>100$ ), significance levels alone might be misleading and indicate only a statistical and not a causal relationship. However, strong relationships between the treering $\delta^{18} \mathrm{O}$ chronologies of Lhamcoka and Ranwu, and partially Reting, are reasonable since moisture reconstructions from these sites rely on the same proxy $\left(\delta^{18} \mathrm{O}\right.$ of tree-ring cellulose) and the trees grown under similar climate conditions. Relationships with the more northern sites (Dunde, Dulan, Qinghai) are difficult to verify according to a clearly detectable westerly influence at these sites. We adapted the colour scheme of Fig. 4 and highlighted the MWP (yellow polygon), LIA (blue polygon), and the remarkable humidity decline since the late 1870s (dashed red line) in Fig. 7. The MWP is characterized by more humid conditions on the eastern TP (Lhamcoka), a drier phase on the central plateau (Reting) and moderate humidity conditions on the northern plateau (Dulan). During the LIA, a remarkable moisture increase occurred at the central and southern plateau (Reting, Dasuopu). Although humidity was high according to these archives, the ASM was weak during that time (Anderson et al., 2002; Gupta et al., 2003).

Thus, the findings for Reting and Dasuopu revealed moisture conditions during cold phases and even drier circumstances during warm periods which might be contrary to findings of Meehl, 1994 and Zhang and Qiu, 2007. The sudden moisture decrease since the late 1870s affects the eastern

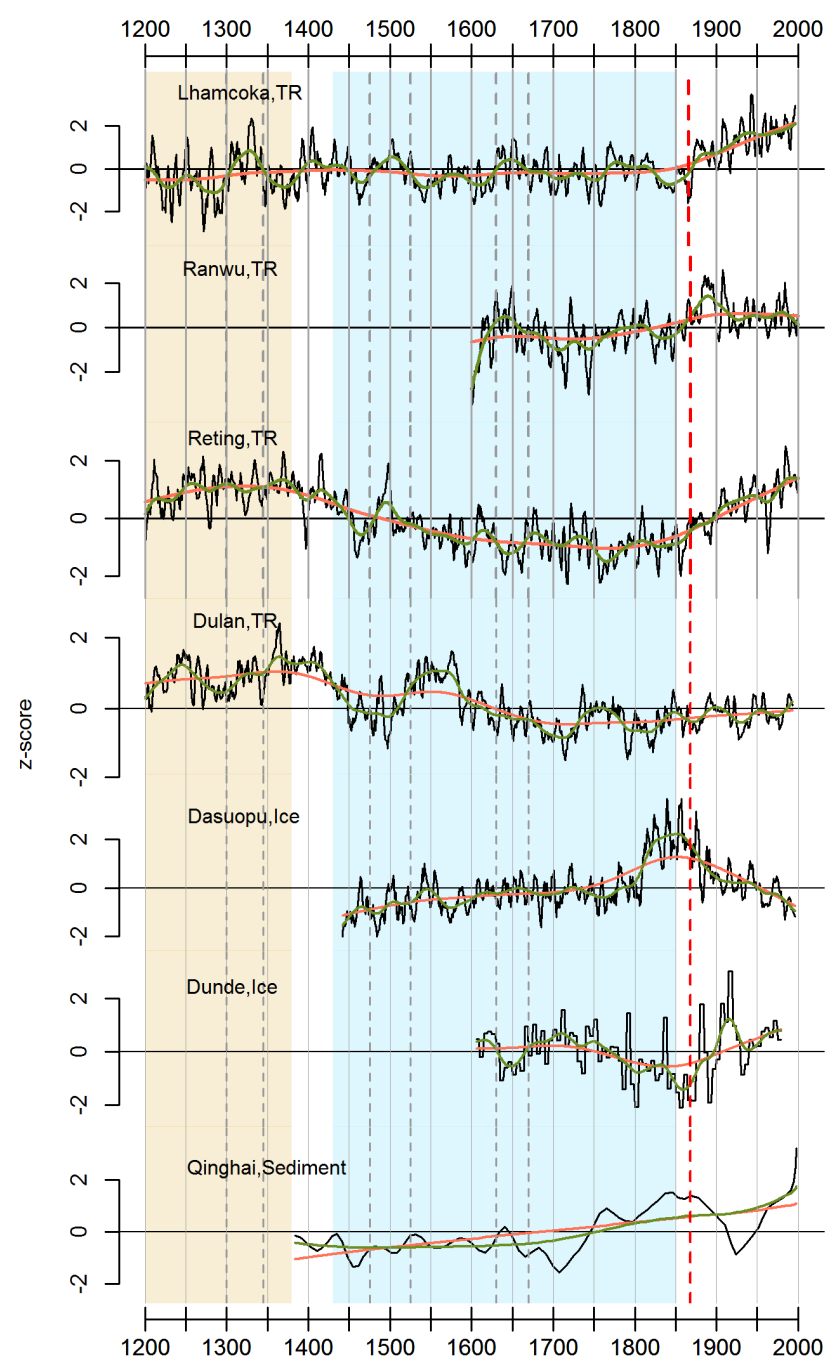

Figure 6. Multiproxy comparison of tree-ring data (TR), ice core, and lake sediment data. TR: Lhamcoka, this study; Ranwu, Liu et al., 2013; Reting, Grießinger et al., 2011; Dulan, Sheppard et al., 2004. Ice: Dasuopu and Dunde, Thompson et al., 2000. Sediment: Qinghai, $\mathrm{Xu}$ et al., 2006a. Locations of the several proxies are shown in Fig. 1. Z-scores were derived from raw proxy data and not from reconstructions. High positive Z-scores indicating dry conditions for TR and sediment records, whereas high Z-scores of ice accumulations represent humid conditions.

(Lhamcoka), southern (Dasuopu), and central (Reting) parts of the TP. Reasons for the sudden moisture decline were discussed in detail by Xu et al., 2012. They address the effect of the moisture decrease on the reduction in the thermal gradient induced by uneven land-ocean temperature rise caused by aerosol and greenhouse gas loads. In fact, under rising northern hemispheric air temperatures (Shi et al., 2013), the air moisture load over sea is increased and the meridional moisture transport is contemporaneously hampered due to the black aerosol induced solar dimming effect (Sun et al., 2010). In addition, Zhao and Moore, 2006 attributed the moisture 


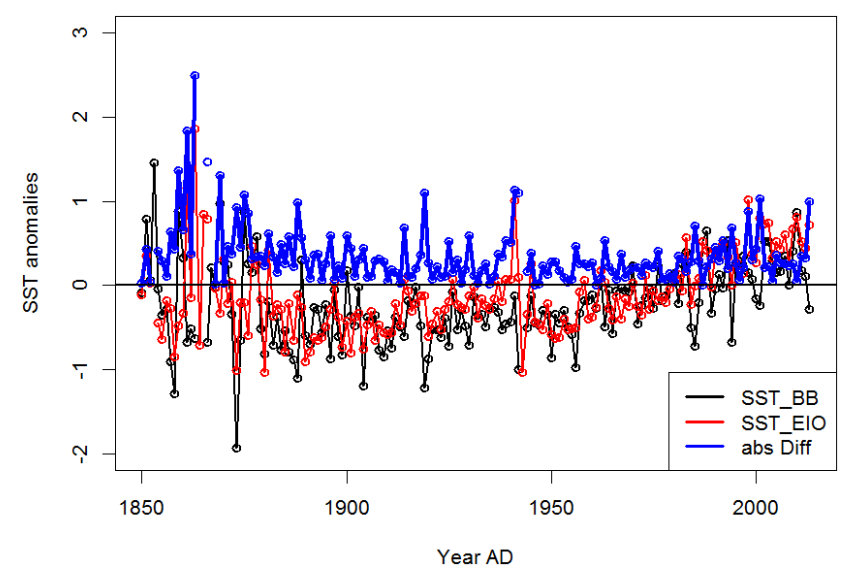

Figure 7. Sea surface temperature anomalies in different regions of the Indian Ocean: Bay of Bengal-North Indian ocean (SST BB: equatorial and northern Indian Ocean $\left(2.5^{\circ} \mathrm{N}-2.5^{\circ} \mathrm{S}, 52.5-\right.$ $\left.112.5^{\circ} \mathrm{E} ; 22.5-27.5^{\circ} \mathrm{N}, 52.5-112.5^{\circ} \mathrm{E}\right)$ and equatorial Indian Ocean (SST EIO: $2.5^{\circ} \mathrm{N}-2.5^{\circ} \mathrm{S}, 52.5-112.5^{\circ} \mathrm{E}$ ) (Rayner et al., 2006). Difference between the two time series is marked with a blue line.

decline to the weakening of the easterly trade wind system along the equatorial Pacific since the middle of 19th century. Moreover, decreasing varve thicknesses imply a weakening Asian summer monsoon over the past 160 years $(\mathrm{Chu}$ et al., 2011). The aforementioned analysis revealed a link to warm phases of ENSO and an anomalous regional Hadley circulation. However, their explanation approach remains incomplete due to dynamic issues associated with rising temperatures and a weakening South Asian summer monsoon. Therefore, a terminal explanation is not given yet and should be discussed in future studies.

In comparison to tree-ring sites located further south (e.g. Liu et al., 2013; Sano et al., 2013; Shi et al., 2012), the distinct humidity decline is more pronounced on the central and eastern TP. From that observation, Sano et al., 2013, concluded that there is a weakening of the monsoon over the last 100-200 years due to uneven SST variation (equatorial vs. northern Indian Ocean regions). To test this hypothesis, we calculated the averaged SST anomalies of the equatorial and northern Indian Ocean $\left(2.5^{\circ} \mathrm{N}-2.5^{\circ} \mathrm{S}, 52.5-112.5^{\circ} \mathrm{E}\right.$; $22.5-27.5^{\circ} \mathrm{N}, 52.5-112.5^{\circ} \mathrm{E}$ ). As shown in Fig. 7, a slight SST increase in both regions beginning in approximately the 1950s is obvious. Besides, the gradient constantly decreases, but has restrengthened since approximately the 1970s. This finding contrasts with a generally weakening monsoon circulation over the past 100-200 years deduced from a thermal gradient reduction. Therefore, the various moisture variations of the southern and central/eastern TP during the last 100-200 years might show influences of varying local air mass characteristics.

\section{Conclusions}

We demonstrated that our 800 -year $\delta^{18} \mathrm{O}$ chronology is suitable for reliable reconstruction of summer relative humidity. Long-term air humidity variations revealed more humid conditions during the termination of the MWP, relatively stable humidity during the LIA, and a sudden decrease in summer humidity beginning in the 1870s. After approximately the 1950s, the trend towards heavier oxygen isotope ratios has been mitigated due to the restrengthening of the ISM. These findings are in accordance with other reconstructions of moisture conditions for the central and eastern TP. Spatial correlations indicate a significant relationship of summer relative humidity at our study site and major parts of the TP. Additionally, a negative correlation within the higher atmosphere over the west central Asia region imply a westerly influence. Furthermore, the thermal contrast between the equatorial and northern Indian Ocean, which is assumed to control moisture supply during the ISM, is slightly stable over time. Thus, to comprehensively indicate reasons for the distinct approximately 1870s moisture decline, more detailed climate dynamic studies and highly resolved spatiotemporal hydroclimate reconstructions are needed.

Acknowledgements. The authors thank the German Federal Ministry of Education and Research (BMBF) for financial support. We also thank Roswitha Höfner-Stich for her efficient and precise work with the mass spectrometer. We would additionally like to thank Thomas Mölg for his inspiring and helpful suggestions.

Edited by: D. Fleitmann

\section{References}

An, W., Liu, X., Leavitt, S., Xu, G., Zeng, X., Wang, W., Qin, D., and Ren, J.: Relative humidity history on the BatangLitang Plateau of western China since 1755 reconstructed from tree-ring $\delta^{18} \mathrm{O}$ and $\delta \mathrm{D}$, Clim. Dynam., 42, 2639-2654, doi:10.1007/s00382-013-1937-z, 2014.

Anderson, D., Overpeck, J., and Gupta, A.: Increase in the Asian Southwest Monsoon During the Past Four Centuries, Science, 297, 596-599, doi:10.1126/science.1072881, 2002.

Anderson, W., Bernasconi, S., and McKenzie, J.: Oxygen and carbon isotopic record of climatic variability in tree ring cellulose (Picea abies)' An example from central Switzerland (19131995), J. Geophys. Res., 103, 31625-31636, 1998.

Araguás-Araguás, L., Fröhlich, K., and Rozanski, K.: Stable isotope composition of precipitation over southeast Asia, J. Geophys. Res. Lett., 103, 721-728, 1998.

Berkelhammer, M. and Stott, L.: Secular temperature trends for the southern Rocky Mountains over the last five centuries, Geophys. Res. Lett., 39, 1-6, doi:10.1029/2012GL052447,, 2012.

Bollasina, M., Ming, Y., and Ramaswamy, V.: Anthropogenic aerosols and the weakening of the South Asian Summer 
Monsoon, Science, 334, 502-505, doi:10.1126/science.1204994, 2011.

Böhner, J.: General climatic controls and topoclimatic variations in Central and High Asia, Boreas, 35, 279-295, 2006.

Böttger, T. and Friedrich, M.: A new serial pooling method of shifted tree ring blocks to construct millennia long tree ring isotope chronologies with annual resolution, Isot. Environ. Healt. S., 45, 68-80, 2009.

Bräuning, A.: Climate history of the Tibetan Plateau during the last 1000 years derived from a network of Juniper chronologies, Dendrochronologia, 19, 127-137, 2001.

Bräuning, A.: Tree-ring evidence of "Little Ice Age" glacier advances in southern Tibet, The Holocene, 16, 369-380, 2006.

Bunn, A.: A dendrochronology program library in $\mathrm{R}$ (dplR), Dendrochronologia, 26, 115-124, doi:10.1016/j.dendro.2008.01.002, 2008.

Burk, R. and Stuiver, M.: Oxygen isotope ratios in trees reflect mean annual temperature and humidity, Science, 27, 1417-1419, 1981.

Cherchi, A. and Navarra, A.: Influence of ENSO and of the Indian Ocean Dipole on the Indian summer monsoon variability, Clim. Dynam., 41, 81-103, doi:0.1007/s00382-012-1602-y, 2013.

Chu, G., Sun, Q., Yang, K., Li, A., Yu, X., Xu, T., Yan, F., Qang, X., Xie, M., Lin, Y., and Liu, Q.: Evidence for decreasing South Asian summer monsoon in the past 160 years from varved sediment in Lake Xinluhai, Tibetan Plateau, J. Geophys. Res., 116, doi:10.1029/2010JD014454, 2011.

Chung, C. and Ramanathan, V.: Weakening of north Indian SST gradients and the Monsoon rainfall in India and the Sahel, J. Climate, 19, 2036-2045, 2006.

Cook, E. and Kairiukstis, L.: Methods of dendrochronology, Kluwer Academic Publishers, Dordrecht, Boston, London, 1990.

Cook, E., Briffa, K., and Jones, P.: Spatial regression methods in dendroclimatology: A review and comparison of two techniques, Int. J. Clim., 14, 379-402, 1994.

Cook, E., Anchukaitis, K., Buckley, B., D’Arrigo, R., Jacoby, G., and Wright, W.: Asian Monsoon Failure and Megadrought During the Last Millennium, Science, 328, 486489, doi:10.1126/science.1185188, 2010.

Ding, Q. and Wang, B.: Circumglobal teleconnection in the northern hemisphere summer, J. Climate, 18, 3483-3505, 2005.

Esper, J., Frank, D., Battipaglia, G., Büntgen, U., Holert, C., Treydte, K., Siegwolf, R., and Saurer, M.: Low-frequency noise in $\delta^{13} \mathrm{C}$ and $\delta^{18} \mathrm{O}$ tree ring data: A case study of Pinus uncinata in the Spanish Pyrenees, Glob. Biogeochem. Cy., 24, 1-11, doi:10.1029/2010GB003772, 2010.

Grießinger, J., Bräuning, A., Helle, G., Thomas, A., and Schleser, G.: Late Holocene Asian summer monsoon variability reflected by $\delta^{18} \mathrm{O}$ in tree-rings from Tibetan junipers, Geophys. Res. Lett., 38, 1-5, doi:10.1029/2010GL045988, 2011.

Gupta, A., Anderson, D., and Overpeck, J.: Abrupt changes in the Asian southwest monsoon during the Holocene and their links to the North Atlantic Ocean, Nature, 421, 354-357, 2003.

Hren, M., Bookhagen, B., Blisniuk, P., Booth, A., and Chamberlain, C.: $\delta^{18} \mathrm{O}$ and $\delta \mathrm{D}$ of streamwaters across the Himalaya and Tibetan Plateau: Implications for moisture sources and paleoelevation reconstructions, Earth Planet. Sci. Lett., 288, 20-32, doi:10.1016/j.epsl.2009.08.041, 2009.

$\mathrm{Hu}, \mathrm{Z} .-\mathrm{Z}$., Latif, M., Roeckner, E., and Bengtsson, L.: Intensified Asian summer monsoon and its variability in a coupled model forced by increasing greenhouse gas concentrations, Geophys. Res. Lett., 27, 2681-2684, 2000.

Immerzeel, W., van Beek, L., and Bierkens, M.: Climate Change will affect the Asia Water Towers, Science, 328, 1382-1385, doi:10.1126/science.1183188, 2010.

Kahmen, A., Simonin, K., Tu, K., Goldsmith, G., and Dawson, T.: The influence of species and growing conditions on the 18-O enrichment of leaf water and its impact on effective path length, New Phytol., 184, 619-630, doi:10.1111/j.14698137.2009.03008.x, 2009.

Kahmen, A., Sachse, D., Arndt, S., Tu, K., Farrington, H., Vitousek, P., and Dawson, T.: Cellulose $\delta^{18} \mathrm{O}$ is an index of leaf-to-air vapor pressure difference (VPD) in tropical plants, P. Natl. Acad. Sci., 108, 1981-1986, www.pnas.org/cgi/doi/10. 1073/pnas.1018906108, 2011.

Kumar, K., Rajagopalan, B., and Cane, M.: On the weakening relationship Between the Indian Monsoon and ENSO, Science, 284, 2156-2159, doi:10.1126/science.284.5423.2156, 1999.

Kumar, K., Rajagopalan, B., Hoerling, M., Bates, G., and Cane, M.: Unraveling the mystery of Indian Monsoon failure during El Nino, Science, 314, 115-119, doi:10.1126/science.1131152, 2006.

Lau, K., Kim, M., and Kim, K.: Asian summer monsoon anomalies induced by aerosol direct forcing: the role of the Tibetan Plateau, Clim. Dynam., 26, 855-864, doi:10.1007/s00382-0060114-z, 2006.

Laumer, W., Andreau, L., Helle, G., Schleser, G., Wieloch, T., and Wissel, H.: A novel approach for the homogenization of cellulose to use micro-amounts for stable isotope analyses, Rapid Commun. Mass Spectrom., 23, 1934-1940, doi:10.1002/rcm.4105, 2009.

Leavitt, S.: Tree-ring C-H-O isotope variability and sampling, Sci. Tot. Environ., 408, 5244-5253, 2010.

Liu, X., An, W., Treydte, K., Shao, X., Leavitt, S., Hou, S., Chen, T., Sun, W., and Qin, D.: Tree-ring $\delta^{18} \mathrm{O}$ in southwestern China linked to variations in regional cloud cover and tropical sea surface temperature, Chem. Geol., 291, 104-115, doi:10.1016/j.chemgeo.2011.10.001, 2012.

Liu, X., Zeng, X., Leavitt, S., Wang, W., An, W., Xu, G., Sun, W., Wang, Y., Qin, D., and Ren, J.: A 400year tree-ring $\delta^{18} \mathrm{O}$ chronology for the southeastern Tibetan Plateau: Implications for inferring variations of the regional hydroclimate, Glob. Planet. Change, 104, 23-33, doi:10.1016/j.gloplacha.2013.02.005, 2013.

Liu, X., Xu, G., Grießinger, J., An, W., Wang, W., Zeng, X., Wu, G., and Qin, D.: A shift in cloud cover over the southeastern Tibetan Plateau since 1600: evidence from regional tree-ring $\delta^{18} \mathrm{O}$ and its linkages to tropical oceans, Quaternary Sci. Rev., 88, 55-68, doi:10.1016/j.quascirev.2014.01.009, 2014.

Liu, Y., Cai, Q., Liu, W., Yang, Y., Sun, J., Song, H., and Li, X.: Monsoon precipitation variation recorded by tree-ring $\delta^{18} \mathrm{O}$ in arid Northwest China since AD 1878, Chem. Geol., 252, 56-61, doi:10.1016/j.chemgeo.2008.01.024, 2008.

Madden, R. and Julian, P.: Observations of the 40-50 day Tropical Oscillation- A review, Month. Weather Rev., 122, 814-837, 1994.

Maussion, F., Scherer, D., Mölg, T., Collier, E., Curio, J., and Finkelnburg, R.: Precipitation seasonality and variability over the 
Tibetan Plateau as resolved by the High Asia Reanalysis, J. Climate, 27, 1910-1927, doi:10.1175/JCLI-D-13-00282.1, 2014.

McCarroll, D. and Loader, N.: Stable isotopes in tree rings, Quaternary Science Review, 23, 771-801, 2004.

Meehl, G.: Influence of the land surface in the Asian Summer Monsoon: External conditions versus internal feedbacks, J. Climate, 7, 1033-1049, 1994.

Mölg, T., Maussion, F., and Scherer, D.: Mid-latitude westerlies as a driver of glacier variability in monsoonal High Asia, Nat. Clim. Change, 4, 68-73, doi:10.1038/NCLIMATE2055, 2014.

Morrill, C., Overpeck, J., and Cole, J.: A synthesis of abrupt changes in the Asian summer monsoon since the last deglaciation, The Holocene, 13, 465-476, 2003.

Park, H.-S. and Chiang, J.: The delayed effect of major El Nino Events on Indian Monsoon Rainfall, J. Climate, 23, 932-946, doi:10.1175/2009JCLI2916.1, 2010.

Pederson, N., Hessl, A., Baatarbileg, N., Anchukaitis, K., and Di Cosmo, N.: Pluvials, droughts, the Mongol Empire, and modern Mongolia, Proceedings of the National Academy of Sciences of the United States of America (PNAS), 111, 4375-4379, doi:10.1073/pnas.1318677111/-/DCSupplemental, 2014.

Ramesh, R., Bhattacharya, S., and Gopalan, K.: Climatic correlations in the stable isotope records of silver fir (Abies pindrow) trees from Kashmir, India, Earth Planet. Sci. Lett., 79, 66-74, 1986.

Rayner, N., Brohan, P., Parker, D., Folland, C., Kennedy, J., Vanicek, M., Ansell, T., and Tett, S.: Improved analyses of changes and uncertainties in sea surface temperature measured in situ since the mid-nineteenth century: the HadSST2 data set, J. Climate, 19, 446-469, 2006.

Roden, J. and Ehleringer, J.: Hydrogen and oxygen isotope ratios of tree ring cellulose for field-grown riparian trees, Oecologia, 123, 481-489, 2000.

Roden, J., Lin, G., and Ehleringer, J.: A mechanistic model for interpretation of hydrogen and oxygen isotope ratios in tree-ring cellulose, Geochim. Cosmochim. Ac., 64, 21-35, 2000.

Saeed, S., Müller, W., Hagemann, S., and Jacob, D.: Circumglobal wave train and the summer monsoon over northwestern India and Pakistan: the explicit role of the surface heat low, Clim. Dynam., 37, 1045-1060, doi:10.1007/s00382-010-0888-x, 2011.

Sano, M., Sheshshayee, M., Managave, S., Ramesh, R., Sukumar, R., and Sweda, T.: Climatic potential of $\delta^{18} \mathrm{O}$ of Abies spectabilis from the Nepal Himalaya, Dendrochronologia, 28, 93-98, doi:10.1016/j.dendro.2009.05.005, 2010.

Sano, M., Ramesh, R., Sheshshayee, M., and Sukumar, R.: Increasing aridity over the past 223 years in the Nepal Himalaya inferred from a tree-ring $\delta^{18} \mathrm{O}$ chronology, The Holocene, 1, 1-9, doi:10.1177/0959683611430338, 2011.

Sano, M., Tshering, P., Komori, J., Fujita, K., Xu, C., and Nakatsuka, T.: May-September precipitation in the Bhutan Himalaya since 1743 as reconstructed from tree ring cellulose $\delta^{18} \mathrm{O}$, J. Geophys. Res. Atmos., 118, 8399-8410, doi:10.1002/jgrd.50664, 2013.

Saurer, M., Aellen, K., and Siegwolf, R.: Correlating $\delta^{13} \mathrm{C}$ and $\delta^{18} \mathrm{O}$ in cellulose of trees, Plant Cell Enviro., 20, 1543-1550, 1997.

Shao, X., Huang, L., Liu, H., Liang, E., Fang, X., and Wang, L.: Reconstruction of precipitation variation from tree rings in recent 1000 years in Delingha, Qinghai, Science in China Ser. D Earth Sciences, 48, 939-949, doi:10.1360/03yd0146, 2005.
Sheppard, P., Tarasov, P., Graumlich, L., Heussner, K.-U., Wagner, M., Österle, H., and Thompson, L.: Annual precipitation since $515 \mathrm{BC}$ reconstructed from living and fossil juniper growth of northeastern Qinghai Province, China, Clim. Dynam., 23, 869881, 2004.

Shi, C., Daux, V., Zhang, Q.-B., Risi, C., Hou, S.-G., Stievenard, M., Pierre, M., Li, Z., and Masson-Delmotte, V.: Reconstruction of southeast Tibetan Plateau summer climate using tree ring $\delta^{18} \mathrm{O}$ : moisture variability over the past two centuries, Clim. Past, 8, 205-213, doi:10.5194/cp-8-205-2012, 2012.

Shi, F., Yang, B., Mairesse, A., von Gunten, L., Li, J., Bräuning, A., Yang, F., and Xiao, X.: Northern Hemisphere temperature reconstruction during the last millennium using multiple annual proxies, Clim. Res., 56, 231-244, doi:10.3354/cr01156, 2013.

Sternberg, L.: Oxygen stable isotope ratios of tree-ring cellulose: the next phase of understanding, New Phytol., 181, 553-562, 2009.

Sun, Y., Ding, Y., and Dai, A.: Changing links between South Asian summer monsoon circulation and tropospheric land-sea thermal contrasts under a warming scenario, Geophys. Res. Lett., 37, 1$5,2010$.

Thomas, A. and Herzfeld, U.: REGEOTOP: New climatic data fields for east asia based on localized relief information and geostatistical methods, Int. J. Climatol., 24, 1283-1306, doi:10.1002/joc.1058, 2004.

Thompson, L., Yao, T., Mosley-Thompson, E., Davis, M., Henderson, K., and Lin, P.-N.: A high- resolution millennial record of the South Asian monsoon from Himalayan ice cores, Science, 289, 1916-1919, doi:10.1126/science.289.5486.1916, 2000.

Tian, L., Yao, T., MacClune, K., White, J., Schilla, A., Vaughn, B., Vachon, R., and Ichiyanagi: Stable isotopic variations in west China: A consideration of moisture sources, J. Geophys. Res., 112, 1-12, doi:10.1029/2006JD007718, 2007.

Treydte, K., Schleser, G., Helle, G., Frank, D., Winiger, M. Haug, G., and Esper, J.: The twentieth century was the wettest period in northern Pakistan over the past millennium, Nature, 440, 11791182, doi:10.1038/nature04743, 2006.

Tsuji, H., Nakatsuka, T., and Takagi, K.: $\delta^{18} \mathrm{O}$ of tree-ring cellulose in two species (spruce and oak) as proxies of precipitation amount and relative humidity in northern Japan, Chem. Geol., 231, 67-76, doi:10.1016/j.chemgeo.2005.12.011, 2006.

Wang, W., Liu, X., Xu, G., Shao, X., Qin, D., Sun, W., An, W., and Zeng, X.: Moisture variations over the past millennium characterized by Qaidam Basin tree-ring $\delta^{18} \mathrm{O}$, Chinese Sci. Bull., 58, 3956-3961, doi:10.1007/s11434-013-5913-0, 2013.

Wang, Y., Jian, Z., and Zhao, P.: Extratropical modulation on Asian summer monsoon at precessional bands, Geophys. Res. Lett., 39, 1-6, doi:10.1029/2012GL052553, 2012.

Webster, P., Magana, V., Palmer, T., Shukla, J., Tomas, R., Yanai, M., and Yasunari, T.: Monsoons: Processes, predictability, and the prospects for prediction, J. Geophys. Res., 103, 1445114510, doi:10.1029/97JC02719, 1998.

Wernicke, J., Grießinger, J., Hochreuther, P., and Bräuning, A.: Variability of summer humidity during the past 800 years on the eastern Tibetan Plateau inferred from $\delta^{18} \mathrm{O}$ of tree-ring cellulose, Clim. Past Discuss., 10, 3327-3356, doi:10.5194/cpd-10-33272014, 2014.

Wieloch, T., Helle, G., Heinrich, I., Voigt, M., and Schyma, P.: A novel device for batch-wise isolation of $\alpha$-cellulose from small- 
amount wholewood samples, Dendrochronologia, 29, 115-117, doi:10.1016/j.dendro.2010.08.008, 2011.

Wigley, T., Briffa, K., and Jones, P.: On the Average Value of Correalted Time Series, with Application in Dendroclimatology and Hydrometeorology, J. Clim. Appl. Meteorol., 23, 201-213, 1984.

$\mathrm{Xu}, \mathrm{C}$., Sano, M., and Nakatsuka, T.: A 400-year record of hydroclimate variability and local ENSO history in northern Southeast Asia inferred from tree-ring $\delta^{18} \mathrm{O}$, Palaeogeogr. Palaeocl., 286, 588-598, doi:10.1016/j.palaeo.2013.06.025, 2013.

$\mathrm{Xu}, \mathrm{H} ., \mathrm{Ai}, \mathrm{L} .$, Tan, L., and An, Z.: Stable isotopes in bulk carbonates and organic matter in recent sediments of Lake Qinghai and their climatic implications, Chem. Geol., 235, 262-275, doi:10.1016/j.chemgeo.2006.07.005, 2006a.

Xu, H., Hong, Y., Lin, Q., Zhu, Y., Hong, B., and Jiang, H.: Temperature responses to quasi-100-yr solar variability during the past 6000 years based on $\delta^{18} \mathrm{O}$ of peat cellulose in Hongyuan, eastern Qinghai-Tibet plateau, China, Palaeogr. Palaeocl., 230, 155-164, doi:10.1016/j.palaeo.2005.07.012, 2006b.

$\mathrm{Xu}, \mathrm{H}$. , Hong, Y., and Hong, B.: Decreasing Asian summer monsoon intensity after $1860 \mathrm{AD}$ in the global warming epoch, Clim. Dynam., 39, 2079-2088, doi:10.1007/s00382-012-1378-0, 2012.

Yang, B., Bräuning, A., and Yafeng, S.: Late Holocene temperature fluctuations on the Tibetan Plateau, Quat. Sci. Rev., 22, 23352344, doi:10.1016/S0277-3791(03)00132-X, 2003.

Yang, B., Qin, C., Wang, J., He, M., Melvin, T., Osborn, T., and Briffa, K.: A 3.500-year tree-ring record of annual precipitation on the northeastern Tibetan Plateau, P. Natl. Acad. Sci. USA, 111, 2903-2908, doi:10.1073/pnas.1319238111, 2013.
Yao, T., Duan, K., Xu, B., Wang, N., Guo, X., and Yang, X.: Precipitation record since AD 1600 from ice cores on the central Tibetan Plateau, Clim. Past, 4, 175-180, doi:10.5194/cp-4-1752008, 2008.

Zang, C. and Biondi, F.: Dendroclimatic calibration in R: The bootRes package for response and correlation function analysis, Dendrochronologia, 31, 68-74, doi:10.1016/j.dendro.2012.08.001, 2012.

Zhang, C.: Madden-Julian oscillation, Reviews of Geophysics, pp. 1-36, 2005.

Zhang, P., Cheng, H., Edwards, R., Chen, F., Wang, Y., Yang, X., Liu, J., Tan, M., Wang, X., Liu, J., An, C., Dai, Z., Zhou, J., Zhang, D., Jia, J., Jin, L., and Johnson, K.: A test of climate, sun, and culture relationships from an 1810-year chinese cave record, Science, 322, 940-942, 2008.

Zhang, Q.-B. and Qiu, H.: A millennium-long treering chronology of Sabina przewalskii on northeastern Qinghai-Tibetan Plateau, Dendrochronologia, 24, 91-95, doi:10.1016/j.dendro.2006.10.009, 2007.

Zhao, H. and Moore, G.: Reduction in Himalayan snow accumulation and weakening of the trade winds over the Pacific since the 1840s, Geophys. Res. Lett., 33, 1-5, doi:10.1029/2006GL027339, 2006.

Zhou, T., Yu, R., Li, H., and Wang, B.: Ocean forcing to changes in global Monsoon precipitation over the recent half-century, $\mathrm{J}$ Climate, 21, 3833-3852, doi:10.1175/2008JCLI2067.1, 2008a.

Zhou, T., Zhang, L., and Li, H.: Changes in global land monsoon area and total rainfall accumulation over the last half century, Geophys. Res. Lett., 35, 1-6, doi:10.1029/2008GL034881, 2008b. 